\title{
The cause, features and effects of current policy mix of opposing fiscal and monetary policies
}

Wei Liu

\section{Correspondence:}

liqinghua158@126.com

Beijing University, Beijing 100871, China

\begin{abstract}
Currently, China's expansionary fiscal policy and tight monetary policy have formed an opposing policy mix. This is due to the imbalanced macro-economy, which suffers from the pressures of inflation and slow growth. In response to economic changes, China adjusted its monetary policy as the real economy has a weak demand for money. In its reactions to the financial crisis, China adopted a series of policies different from those implemented in European and American countries. For this mix of opposing fiscal and monetary policies to be effective, three conditions should be met: the adjustment of direction should fit the real imbalanced economic situation, financing and investing mechanisms should be market-based, interest rates and exchange rates should gradually become market-determined.
\end{abstract}

Keywords: Macro-control; Fiscal policy; Monetary policy; Mix of easing and tight policy

\section{Causes for the mix of opposing policies}

The mix of opposing policies refers to the combination of proactive (expansionary) fiscal policy being implemented in parallel with prudent (tight) monetary policy. This combination was put in place in China between 2003 and 2007 before the 2008 financial crisis broke out. From 1999 to 2007, China had proactive fiscal policies and prudent monetary policies. Yet, before the fourth quarter of 2003, the monetary policies had not imposed much of a tightening effect as the required reserve ratio was kept at a relatively low level of $6 \%$ to $8 \%$ and was decreasing year by year from 1999 to 2003. From the fourth quarter of 2003 onwards, monetary policy was tightened with an increase in required reserve ratio. Required reserve ratio increased from $6 \%$ by the end of 2003 to $17.5 \%$ by the third quarter of 2009. In the period from 2003 to 2007, fiscal policy and monetary policy had been a sharp contrast. The main reason lies in the fact that in the imbalanced macro-economy in China, there was an overheated demand for investment yet an overcapacity in producing consumer goods. The opposing trends in investment and consumption made neither an expansionary nor a tight policy kit possible. An expansionary policy kit would help to boost consumption and digest extra productivity but would create even more demand for investment. Likewise, a tight policy kit would help to strike a balance between demand and supply in the investment market but would make things worse in the consumption sector. A sector-specific adjustment in structure that aimed to discourage investment and encourage consumption would lead to little policy effect as a result of the offset. This

(c) 2014 Liu; licensee Springer. This is an Open Access article distributed under the terms of the Creative Commons Attribution License (http://creativecommons.org/licenses/by/2.0), which permits unrestricted use, distribution, and reproduction in any medium, provided the original work is properly cited. 
is because a conservative investment market with little expansion would end up with little increase in salaries and funds for consumption and thus end up reducing consumption. Similarly, if it were to encourage consumption, demand for investment would rise, as there would be a need to increase productivity. Facing imbalances in investment and consumption, it would be immature to stick to a single policy direction before figuring out which imbalance would pose the primary threat. Under this situation, it is plausible to have a policy combination of expansionary fiscal policy and tight monetary policy to greatly reduce policy risks, though the effect might be undermined.

When the 2008 financial crisis lashed China's economy, China opted for an overall expansionary economic policy, i.e. a more proactive fiscal policy and a relatively loose monetary policy, switching the policy mix to the expansionary direction. For a year's time from the third quarter of 2009, the required reserve ratio dropped from $17.5 \%$ to 15.5\%. It was more than 2 years until October 2010 when the macro-economic policy changed again. From that time onwards, expansionary macro-economic policy changed to an opt-out-when-appropriate direction. Facing pressures of inflation and slowing economic growth, China again adopted a mix of proactive fiscal policy and prudent monetary policy. Compared with the 'more proactive fiscal policy' in the past that aimed at cushioning the impact of the financial crisis, this time the policy was still an expansionary policy, even though it placed controls on the fiscal deficit and government debt. At the same time, a prudent monetary policy that put inflation prevention as its priority replaced the easing policy of the past. By using monetary instruments such as the required reserve ratio and central bank bills, the policy tightened the control of the money supply. As a result, the required reserve ratio grew from $15.5 \%$ in 2009 to $20.5 \%$ in the second quarter of 2011, and the interest rate for central bank bills grew from $1.5 \%$ in July 2009 to $3.5 \%$ in 2011 (Yao and Tan 2011).

The root cause for the mix, though, was different from that in 2003 to 2007. Then, the combination of opposing fiscal and monetary policies was adopted to tackle the structural imbalances in investment and consumption. The policy combination implemented since late 2010 is due to the overall imbalance at the macro-economic level. As the economy had undergone 2 years of general expansion, by late 2010, inflationary pressures accumulated significantly for the following four reasons. First, after more than 2 years of expansion, in 2010, significant, lagging inflationary pressure began to influence the economy by creating demand in the market. Second, China's economy entered the middle-income stage and saw cost pressures booming. Third, as China's economy has become more closely linked with the world economy, inflation coming from the international market has become more visible at home. Lastly, the imbalance in the international balance of payments severely impacted domestic money supply. The yuan equivalent of foreign exchange holdings caused by the continued increase in foreign currency reserves became the biggest reason for the increase of money supply.

As inflationary pressures have intensified, the general economy has been under a growing threat of a downturn for the following four reasons. First, the lack of motivation for technological innovation in companies has weakened domestic demand and intensified already severe domestic contradictions. In particular, large and extralarge state-owned enterprises (SOEs) have not made sufficient technological advances, leaving little room for industrial upgrading and few opportunities for investment. 
Suffering from a systemic bottleneck, SOEs have been protected from market competition and unwilling to develop their own new technologies. Second, market-oriented reforms have lagged, and there has been little progress in systemic innovation. Companies in the market, especially private medium- and small-size companies, find it hard to get funding from the monetary or capital markets even through normal market channels. Third, there are contradictions in income distribution. On the macro-level, resident income growth has long lagged far behind government and corporate income growth. The ratio of resident income to the general income decreases annually, leaving resident income growth sluggish compared with general economic growth. On the micro-level, the income gap has widened between individuals, between residents of the city and those of the countryside, and between those in different industries and areas, undermining overall appetite for consumption. Moreover, a feature of China's current economic mechanism is its strong power to stimulate investment. When domestic demand needs to be boosted, investment is the first stimulus to be introduced, which in turn hinders the growth in consumption. According to estimates, since the reform and opening, China's fixed-asset investment has grown by approximately $13.5 \%$ annually (excluding price factors) with an $11 \%$ standard deviation. If the fixed-asset growth rate is below $24.5 \%$, the growth rate in consumption demand slows by over $0.5 \%$ for every $1 \%$ growth in fixed-asset investment. If the growth rate is over $24.5 \%$, the growth in consumption demand slows by over $0.8 \%$. If the rate is over $30 \%$, the consumption demand shrinks as fixed-asset investment rises (Liu 2011). Fourth, the world economy has had a sluggish recovery coupled with occasional protectionism. China's exports have faced challenges in the international economy, politics, culture and other areas. From 2000 until the outbreak of the global financial crisis, China's export growth rate stood at over $20 \%$ for most of the time and accounted for $2 \%$ to $3 \%$ of gross domestic product (GDP) growth. So when the export growth rate fell or exports contracted (as in 2009), the overall economy suffered. The policymakers need to, on one hand, avoid inflation and, on the other hand, avoid economic downturn, but neither target seems to have had absolute priority over the other. A combination of expansionary fiscal policy and tight monetary policy became a natural choice.

\section{Features of the current mix of opposing policies}

The current policy mix of expansionary fiscal policy and tight monetary policy has the following characteristics:

1. In adjusting the policy mix, policymakers changed the direction of monetary policy and kept the expansionary fiscal policy unchanged. The change of direction in monetary policy was not due to a sudden demand for money from the real economy, but was the result of a change in the reasonable supply of money. After the financial crisis, in order to better respond to the crisis, in the case of deflationary pressure, monetary supply should have increased. But as inflationary pressure gained intensity, the rate of increase of the money supply should have been controlled.

In the academic literature on economic thinking and policies, there are severe differences in answers to the question of whether monetary policy or fiscal policy is more important. The various schools of economics - Keynesianism, Monetarism, 
New Classical Economics, New Keynesianism and Rational Expectation - all have their own interpretation. From the 1950s to 1970s, Western developed countries advocated Keynesianism, believing that 'fiscal policy is the most important, but monetary policy is important too', and enjoyed over two decades of healthy economic growth. With the emergence of new problems such as 'stagnation' after the 1970s, Keynesianism seemed to have failed. In practice, expansionary monetary policy was deployed to intensify demand, particularly to change the low-efficient demand into valid demand for funding expansion. This expansionary monetary policy was also meant to reduce costs, especially corporate financing costs, and thus boost the economy. It thus relieved inflationary pressure caused by costs so as to solve the problem of stagnation.

However, the expansion came at the expense of lower efficiency and competition standards. Seemingly, monetary tools that reduced interest rates for financing companies helped to reduce financing cost, relieve inflation pressure, stimulate investment demand and finally boost economy and solve stagnation. But in reality, the mode of undermining long-term efficiency was unsustainable. The 2008 world financial crisis was the result of 'bubbles' caused by such a low-efficient, expansionary monetary policy.

Facing economic recession, monetary policies such as pricing tools could hardly stimulate the economy, and officials turned to expansionary fiscal policy, especially expansionary government expenditure policy, leaving monetary policy at a subordinate position. America's so-called quantitative easy monetary policy was actually meant to set its money supply based on the policy requirements of fiscal stimulus. In other words, in reacting to the financial crisis, American and European countries focused on their fiscal policies whilst putting monetary policy relatively unchanged or slightly changed to cater for the fiscal policy.

Things went differently in China. In the second half of 1998, China began to enact proactive fiscal policy to cushion the impact of the Asian financial crisis. From 2003 to 2007, to balance its economic structure, China employed a combination of proactive fiscal policy and prudent monetary policy. From 2008 to 2010, in reaction to the global financial crisis, China made its fiscal policy more active and opted for a moderately loose monetary policy. From the second half of 2010 to today, after multiple rounds of stimulus, China moved back to a proactive fiscal policy and prudent monetary policy. During all these times, the expansionary direction for fiscal policy remained unchanged. Only the degree of expansion changed before and after the crisis. Nevertheless, monetary policy changed direction twice. Over the crisis, prudent (tight) policy changed to easing (expansionary) policy and then to prudent (tight) policy. Expansionary fiscal policy drove up the money supply. Easing monetary policy in Western countries did not restrict their fiscal policy deployment. However, tight monetary policy in China did.

2. Compared with monetary policies of the rest of the world, especially Western countries, policy in China changed more rapidly and significantly, as reflected in the following features.

First, at the beginning of the financial crisis, China adopted a macro-economic policy that was the opposite of those in Western countries. Breaking out in the USA in 2007, the crisis spread across the world in 2008. Most countries opted for 
expansionary macro-economic policy as a response. In contrast, by the beginning of 2008, China was employing an overall tight macro-economic policy that aimed to avoid an overheated economy and inflation. Tight monetary policy was set to cool down overheated demand for investment triggered by the fast economic growth between 2003 and 2007 (the growth rate over this period was over 10\%). Only 6 months after the policy was set, the financial crisis started to take its toll on China's economy. After June 2008, the target of macro-economic policy was to 'maintain growth, control prices, and optimise the structure', with economic growth set as the top priority and price control as the second. Therefore, expansionary macroeconomic policy replaced tight policy. As the financial crisis worsened, by the end of 2008, the general target was to 'maintain, expand domestic demand, and optimise structure'. Inflation prevention was no longer one of the macro-economic goals and an expansionary policy was in full swing. The question is, in the first half of 2008, should China have opted for tight policy instead of the expansionary policies chosen by Western countries?

Second, because China took action later than Western countries, its expansionary policy was strong once announced, which was known as 'a more proactive fiscal policy and a relatively loose monetary policy'. The powerful expansionary policy was best reflected in the investment expenditure plan of 4 trillion RMB of investment in 2 years. The loose monetary policy could be seen in the growth rates of M2 and in monetary instruments such as banking loans. Fiscal deficit skyrocketed from a few hundred billion RMB to 950 billion, approaching the red line of 3\% of GDP ${ }^{a}$. In terms of money quantity, in 2008, newly issued loans amounted to 4.6 trillion RMB and were mostly issued in the second half of the year. In 2009, the figure doubled to 9.6 trillion RMB. For the first half of 2010, similar to the previous year, 4.6 trillion RMB more loans were issued, leaving the growth rate of M2 as high as $27 \%$ in 2009. Should expansionary policy have been so strong in such a short time? As for tackling the financial crisis in the short run, the expansionary macro-economic policy brought considerable growth. In 2008, China's economy grew by $9 \%$. In 2009, it grew by $8.7 \%$ against the global downturn and over $10.3 \%$ in 2010 and $9.2 \%$ in 2011. In the long term, however, the policy aggravated a series of hidden contradictions by creating significant inflationary pressure and undermining efficiency brought by market competition. If this continues, the sustainability of the economy will suffer. As the imbalances have different root causes, similar policies could bring different results.

Third, the imbalances in the supply and demand for money in the market have different root causes, and employing the same policies can have different effects. At the outbreak of the financial crisis, China had abundant money supply while Western countries were short in money supply. In Europe and America, the crisis stemmed from the financial sector, not the real economy. In the capital markets, the real economy had a need for money, and the need became direr as financial institutions such as banks increased their reserves. Unfortunately, banks and financial institutions were in deep crisis due to their own fragile capital chains, and their money supply (loans) and money mobility were weak. In other words, the demand for money increased at a time when there was a shortage of supply. This was the after-effect of the previous expansionary monetary policy, which interfered 
with the normal operation of the money supply mechanism as the bubble burst. Before Western financial institutions returned to normal operation, the money supply mechanism could not meet the demand for money from the real economy. The supply-demand imbalance urged the government to drive money supply through macro-level policy, for instance, by providing funding to banks so that banks could give out loans or by providing funding directly to the real economy to ease the thirst for money. For China, however, the financial crisis came as an external factor. The world economy went into recession as the financial crisis took its toll. Part of China's real economy was first directly affected by the financial crisis. Gradually, general economic growth slowed. For various reasons including mechanism-related ones, financial institutions of China were not affected by the world financial crisis at first. Besides, Chinese citizens have long had a strong willingness to save. Therefore, China's banking system was steady and with good money mobility. This can be proved by the fact that by the end of 2009, the difference between savings and loans in China's banks was 19 trillion RMB (Su et al. 2009). In contrast to the situation in Western countries' money supply and demand situation, China's real economy could not form enough demand for capital even though its banks were abundant in money supply.

Due to insufficient technological innovation and systemic reform, lack of demand for investment capital has long been a problem in China's real economy and became even worse as financial crisis struck. To solve this contradiction, the government should focus on boosting concrete demand for investment in the real economy, rather than increasing money supply as in Western countries. Concrete demand for investment capital lies in technical and institutional innovation, especially in pushing forward the marketization of the financial system and production elements, in deepening the reform of SOEs and breaking up monopolies, and in developing small and medium enterprises by creating a friendly business environment. The short-term policies should, on one hand, encourage investment and, on the other hand, help companies to upgrade technology, improve efficiency and reduce costs. But in reality, China's government opted for an expansionary policy that increased the money supply. Though this brought obvious growth, the price was high. In the long term, proactive fiscal policy cannot introduce more investment demand into China's real economy. Fourth, China 'withdrew' its monetary policy first. After October 2010, China stopped its overall expansionary policy and 'opted out' for a 'proactive fiscal policy and prudent monetary policy' earlier than Western countries did. The reasons were that China's economy still enjoyed quick growth under the financial crisis and that expansion brought with it significant inflation pressure. In 'opting out', monetary policy was the first to change. Its direction changed from 'loose' to 'tight'. This directional change occurred because China suffered from heavy inflationary pressure from tackling the financial crisis with an expansionary policy. The policy set at that time did not ease the supply-demand tension but worsened it. China changed its expansionary monetary policy earlier than Western countries. In October 2010, Western countries started to further stimulate their economies through expansionary fiscal policy. At this time, China had already employed a tight monetary policy and lowered the degree of expansion in its fiscal policy. 


\section{The effect of a mix of opposing monetary and fiscal policies}

There are generally two circumstances under which opposing monetary and fiscal policies will create the desired effect. First, when the imbalance in the macro-economy is unclear or the degree of imbalance is not completely clear. In this case, if fiscal and monetary policies are both expansionary or both tight, the macro-economy would be subject to great ups and downs and suffer from instability; in the case where there was imbalance in different areas (e.g. investment and consumption) and regions (developed and undeveloped regions), if fiscal and monetary policies are both expansionary or tight, the structural imbalance would become worse; in the case where the economy is facing a stagnation threat, and the culprit of the threat is unclear, a combination of expansionary or tight fiscal and monetary policy would ease one conflict but intensify the other.

As so, a mix of expansionary fiscal policy and tight monetary policy reduces the policy risk and may help to rebalance economic growth. The other case where a reversed policy mix may be applicable is where the national economy and international balance of payments both suffered from imbalances and require policies with opposite directions. The policies are tailor-made according to the requirements of the national economy and international balance of payments respectively and have their own features.

It needs to be said that in the two cases described above, for an expansionary-tight mix to work, prerequisites must be met.

1. When the general imbalance is not clear, or the economy may suffer from stagnation, the government should consider the features of both fiscal policy and monetary policy and their long-term and short-term effects respectively before implementing a combination and make infrequent adjustments to the combination. Generally speaking, when facing economic downturn caused by financial crisis, monetary policy is used to control the short-term prices and fiscal policy to keep the economy growing. Evidence shows that the 'monetary policy index (MPI) is a positive factor in lowering inflation during a crisis and the year after, but no statistical significance is found for the third year after a crisis.' 'MPI does not significantly affect the statistics of economic growth during and after the crisis.' 'The fiscal policy index (FPI) has a significant positive impact on the lowest GDP growth rate and average GDP growth rate during a crisis', and 'FPI does not significantly affect the statistics of inflation levels after a crisis.' However, 'after a crisis, the positive impact upon the economy from expansionary fiscal policy would not last long; the deficit that came alone with the policy would start to take its toll around three years after the crisis.'

In short, in reaction to crisis, a change in monetary policy would quickly be reflected in prices and relief from deflation, but the effect would diminish as time passed. If faced with concurrent pressures for stagnation and inflation, expansionary monetary policy would only worsen the inflation but fail to power economic growth. Short-term growth stimulated by expansionary fiscal policy needs to be paid for in the years to come as inflation would gradually appear. Moreover, expansionary fiscal policy cannot guarantee growth in the long term; it even hinders growth. Tight fiscal policy, although it might undermine growth in the short run, 
would help to control post-crisis inflation. Facing dual threats of stagnation and inflation, fiscal policy could be resorted to as a temporary solution to stimulate growth with caution in order to relieve the inflationary pressure that comes after the crisis. In short, under the threats of inflation and economic downturn, the policy mix should basically consist of moderately expansionary fiscal policy and moderately tight monetary policy. It should be noted that expansionary policy should not last too long and while it is in effect, monetary policy should not be highly expansionary so that short-term inflation can be avoided. When crisis has passed, expansionary fiscal policy should be withdrawn on time; otherwise, lagging inflation will increase and drag down growth.

In the battle against this financial crisis, China had an expansionary (more proactive than before) fiscal policy and an expansionary (moderately loose) monetary policy. However, facing crisis, the government should have avoided highly expansionary monetary policy, especially at a time when it came with a threat of 'stagflation', as it was unlikely to stimulate growth in the short term. At the same time as stimulating short-term growth, this formed significant inflationary pressure and forced the government to withdraw monetary policy at an early date. After the policy was withdrawn in the second half of 2010, fiscal policy was still in line with the expansionary direction whereas monetary policy was placed once again in the prudent direction. But if expansionary fiscal policy continued, it would harm rather than benefit long-term economic growth. Expansionary monetary policy would not bring notable impact on the long-term price level. That said, with stagflation hovering, normally the government should have employed a moderately loose monetary policy and moderately tight fiscal policy as a combination, instead of the other way round. Why has China adopted a proactive fiscal policy and prudent monetary policy? The main reason is that the usage of a mix of opposing fiscal and monetary policy should go together with the market on the micro-level. When the market failed to function in the crisis, especially when investment demand from the market was weak and dragged the economy down, the market needed governmental stimulus through fiscal policy. In the following recovery, the timing of the withdrawal of expansionary fiscal policy should depend on the performance of the market. If the market is not mature enough to create concrete demand, expansionary fiscal policy is needed. If that were the case, a long-term expansionary fiscal policy would harm the economic growth and be bound with significant inflationary pressure.

2. Facing imbalances in the domestic economic environment and in the international balance of payments, a mix of opposing fiscal and monetary policy may help to strike a balance in both fields. This is because fiscal policy is more closely related to national economy while monetary policy is more related to the external economic environment. When the economy suffers from unemployment and sluggish growth domestically with a deficit in the international balance of payments, expansionary fiscal policy would help to stimulate general demand and create jobs. Although enlarged demand might drive up imports and increase the deficit in the international balance of payments, fiscal policy would affect the national economy more than the international economy. Logically, it would boost general demand (national income) first and then be reflected in the international balance of 
payments. The job opportunities created by new demand could more than offset the international deficit it brings. On the other hand, tight monetary policy that pushes up interest rates and welcomes capital inflow would help to rebalance the international balance of payments but suppress demand and worsen the unemployment situation. If one considers the short-term impact only, monetary policy would affect the international environment more than the domestic environment.

Tight monetary policy does less harm in terms of demand suppression than the good it does in bridging the deficit. In this case, a combination of expansionary fiscal policy and tight monetary policy can help to achieve the targets of stimulating general demand and reducing the international deficit. Following the same logic, when domestic demand is booming with inflation and good international savings, a tight fiscal policy helps to cool down demand and an expansionary monetary policy keeps interest rates low and urges capital outflow so as to nudge international payments to a balance. Of course, while a tight fiscal policy cools demand, exports would increase while imports drop, and thus, the international account would see more savings. But fiscal policy works better internally than externally. While increasing capital outflows, an expansionary monetary policy also stimulates aggregate demand and worsens inflation. But monetary policy has more salient effect on the outside environment than on the national economy. With this said, a mix of opposing fiscal policy and monetary policy would work.

However, there are two conditions under which such a mix can work effectively. First, the direction of the opposing mix should be in line with the situation. Either domestic demand needs to be boosted and there is a significant deficit in the international balance of payments or domestic demand needs to be cooled down and there is a significant surplus in the international balance of payments. For the former, a combination of expansionary fiscal policy and tight monetary policy is feasible; for the latter, the opposite is true. Currently, China has a shortage of demand but runs a surplus in its international balance of payments, so it meets neither of these conditions. The opposing combination of policies has done little to change the status quo in China, but nor has it produced significant unwanted effects. An important reason is that the capital account is not yet fully convertible, and the current account is more sensitive to the exchange rate. Tight monetary policy does not impose significant appreciation pressure upon the RMB but rather affects exports. The international surplus would not accelerate its rise, then, but rather slow its growth. However, as the market increasingly sets interest rates and the capital account enjoys more and more convertibility, the current opposing policy mix would take its toll on the national economy and international balance of payments over time. To be more specific, the long-term expansionary fiscal policy slows economic growth and worsens the inflation, while tight monetary policy suffocates the economic growth and increases the international surplus.

Second, to rebalance the national economy and international balance of payments by an opposing policy mix requires a change to the mechanism. Marketization of interest rates and the exchange rate has to be stepped up. If not, interest rates cannot react quickly and sensitively to changes to demand and supply in the 
market, rise to attract capital when monetary policy tightens or fall to push capital out when monetary policy expands. As required for interest rates, the exchange rate should be freer and more subject to changes in the market. With fewer non-market uncertainties and risks, capital would enjoy a faster inflow and outflow. Otherwise, monetary policy would do little to balance international payments. Obviously, we are still some time away from truly market-oriented interest rates and the exchange rate in China. It is too early to say if the current market mechanism meets the conditions for an opposing policy mix to attain the targets of balancing the national economy and international payments.

\section{Conclusion and thoughts}

The root cause for an opposing policy mix lies in the particularities of the imbalance in China's macro-economy, which faces the dual threats of inflation and economic downturn. This is the difference with the proactive (expansionary) fiscal policy and prudent (slightly tight) monetary policy employed from 2003 to 2007 when investment demand was overheated and there was insufficient consumption. Today, however, the risk is stagflation.

Second, China chose a different macro-economic direction during the financial crisis compared with Western countries. First, in adjusting the direction of policy, China shifted expansionary monetary policy to a tight one while maintaining and stepping up expansionary fiscal policy. Western countries, however, made fiscal policy their primary tool with monetary policy as only a supplementary tool. Second, China's policy changed at a quicker pace. From the second half of 2007 to the first half of 2008 when financial crisis was budding, China adopted an all-tight (dual prevention) policy mix. During the peak of the crisis, China deployed highly expansionary fiscal and monetary policies. In a capital market that had a different imbalance from Western countries, inflationary pressure was increasing, forcing China to withdraw expansionary policies sooner than other countries. By the end of 2010, when others were still expanding their economies, China 'withdrew when appropriate' and resorted to an opposing policy mix. Third, China's real economy did not have enough demand for money, which set it apart from Western countries. If China chose to increase the supply of money, it could trigger short-term demand and economic growth but would likely result in serious inflation.

Third, given that the macro-economy was under the threat of stagflation, a working opposing policy mix was an expansionary fiscal policy (to cushion the impact of the crisis) and a moderately tight monetary policy. When the crisis had passed, a mix of a moderately tight fiscal policy and a moderately loose monetary policy seemed more appropriate as the government gradually shed of the role of stimulating the economy. However, to achieve this directional transition, investment and financing activities should have been conducted under a market-led mechanism rather than a governmentled mechanism. If not, market forces would never be able to take over the role of expansionary fiscal policy in influencing the market, even in prosperous times. Given imbalances in the national economy and the international balance of payments, an opposing policy mix that aims to solve both problems at once can only work with market-set interest and exchange rates. If this prerequisite cannot be met, macroeconomic policy adjustment cannot touch upon the international balance of payments. 
As the above mechanism condition could not be met, China adopted an opposite policy mix from Western countries. The policy mix resulted in considerable short-term growth, unfortunately, at high long-term cost.

Clearly, when under the threat of stagflation and expansionary policy is forced 'to be withdrawn when appropriate', the following issues should be properly dealt with for sustainable and balanced economic growth to be achieved: (1) In matching fiscal and monetary policies, avoid long-term highly expansionary fiscal policy and try to employ a moderately loose monetary policy to the extent possible rather than the other way round. (2) In adjusting the economy on macro-level, focus on the management of demand as well as supply. Macro-economic policy affects both demand and supply. If supply continues to be ignored, rebalancing the economy, corporate efficiency, productivity, industrial restructuring and innovation can never make progress. (3) In terms of setting policy direction, policymakers should fine tune the direction in a timely manner as the contradictions of the macro-economy change. When making major decisions, policymakers should follow a more democratic, law-based and procedure-abiding method so that the conflicts of interests between central and local governments, governments and enterprises, fiscal and financing bodies, banks and companies, and SOEs and private companies can be coordinated and well balanced. In fact, adjustment of macro-economic policy is always aimed at protecting the interest of one party in the economy and depriving another. If the interests cannot be well balanced between parties, conflicts will surely become more intense. (4) When talking about mechanism innovation, we should continue to deepen reforms for a socialist market economy and work intensively on the marketization of elements such as land, labour, capital and foreign currencies and on building a market competition mechanism. Without proper marketization, macro-economic policy can hardly realise its desired effect and working fiscal and monetary policy mix, and supply management and balance of interests will be difficult to achieve.

\section{Endnote}

according to the Maastricht Treaty (formally the Treaty on European Union), member states' deficits should be lower than 3\% of the GPD and debt lower than $60 \%$ of the GDP.

\section{Competing interests}

The author declares that he has no competing interests.

Author's information

Wei Liu, born in 1957, is the Vice President of Peking University, the Vice Chairman of the Steering Committee for Economics under the Ministry of Education, a member of the Theoretic Economics Division of the Academic Degree Committee of the State Council, a member of the Standing Committee of the Beijing Municipal Committee of the Chinese People's Political Consultative Conference and the Vice Chairman of the Chinese Finance Society. He is a holder of government allowance, a member of the first batch of Trans-Century Talents (Arts) for the State Education Commission, one of the State Class Persons of National Talents from the Ministry of Personnel and six other ministries, and a Distinguished Professor of Peking University from the Chang Jiang Scholars Programme under the Ministry of Education.

Disclosure

This is an interim report of 'Study on China's Mid-long Term Economic Growth and Structural Transition' (Project Code: 09AZD013), a key project of the National Social Science Foundation, published in Economics Perspectives, 2010, No. 7. 
Received: 2 January 2013 Accepted: 8 November 2013

Published: 2 January 2014

\section{References}

Liu W (2011) Economic growth in transitive economy (转轨中的经济增长). Beijing Normal University Publishing Group (北京师范大学出版社), Beiijing

Su J, Lin WB, Ye HY (2009) Difference of the economic situation in China and the U.S amidst the financial crisis and choice of monetary policies (金融危机下中美经济形势的差异与货币政策的选择). Econ Perspect (经济学动态) 9:57-63

Yao YD, Tan HM (2011) Central bank bill interest rate can act as a comprehensive indicator of monetary policy (央票利率可以作为货币政策的综合性指标). Economic Research Journal (经济研究) 2

\section{doi:10.1186/2196-5633-2-1}

Cite this article as: Liu: The cause, features and effects of current policy mix of opposing fiscal and monetary policies. China Finance and Economic Review 2014 2:1.

\section{Submit your manuscript to a SpringerOpen ${ }^{\circ}$} journal and benefit from:

- Convenient online submission

- Rigorous peer review

- Immediate publication on acceptance

- Open access: articles freely available online

- High visibility within the field

Retaining the copyright to your article 